\title{
Analisis High Order Thinking Skill (HOTs) pada Tujuan dan Asesmen Mata Pelajaran Kimia
}

\author{
Dinyah Rizki Yanti Zebua ${ }^{1}$, Harmalis ${ }^{2}$ \\ ${ }^{1,2}$ Institut Agama Islam Negeri Kerinci, Jln. KaptenMuradi Sungai Liuk, Sungai Penuh, Indonesia \\ dinyahryzebua@gmail.com
}

\begin{abstract}
The purpose of this study was to analyze the High Order Thinking Skill (HOTS) on learning purposes and assessments as well as the suitability of HOTS on the learning purposes and assessments in the Chemistry subject especially on Acid and Basa Concept. This research was classified as qualitative research with content analysis. Content analysis is a research method that discusses in depth the contents of written or printed information in a mass media. The informant of this research is the document of the Learning Implementation Plan and daily test questions obtained from the Chemistry teachers at SMA Negeri 2 Sungai Penuh. The results of this study were (1) HOTS has been contained in the learning purposes of chemistry in the Acid and Basa Concept at SMA Negeri 2 Sungai Penuh, among the 7 learning purposes, just 4 of them are learning purposes that contain HOTS; (2) HOTS has been contained in the Chemistry Learning Assessment in the Acid and Basa Concept at SMA Negeri 2 Sungai Penuh. There was only one assessment question that contains the HOTS; and (3) there was no relevance between the HOTS that contained in the learning purposes and assessment on the Acid and Basa Concept at SMA Negeri 2 Sungai Penuh.
\end{abstract}

Keywords: High Order Thinking Skill (HOTS), Purpose of Learning, Assessment, Bloom's Taxonomy

\begin{abstract}
Abstrak
Penelitian ini bertujuan untuk menganalisis High Order Thinking Skill (HOTS) pada tujuan dan asesmen pembelajaran serta kesesuaian antara HOTS pada tujuan dan asesmen pada mata pelajaran Kimia materi Konsep Asam Basa. Penelitian ini tergolong penelitian kualitatif dengan analisis isi (content analysis). Analisis isi merupakan metode penelitian yang membahas secara mendalam isi suatu informasi tertulis atau tercetak dalam suatu media massa. Informan penelitian ini adalah dokumen Rencana Pelaksanaan Pembelajaran dan soal ulangan harian yang didapat dari guru Kimia SMA Negeri 2 Sungai Penuh. Hasil Penelitian ini adalah (1) HOTS telah terkandung dalam tujuan pembelajaran Kimia pada Konsep Asam Basa di SMA Negeri 2 Sungai Penuh, diantara 7 buah tujuan pembelajaran, 4 diantaranya merupakan tujuan pembelajaran yang mengandung HOTS; (2) HOTS telah terkandung dalam asesmen pembelajaran Kimia pada Konsep Asam Basa di SMA Negeri 2 Sungai Penuh, tetapi hanya terdapat pada satu soal asesmen; dan (3) tidak terdapat relevansi antara HOTS yang terkandung dalam tujuan pembelajaran dan asesmen pembelajaran Kimia pada Konsep Asam Basa di SMA Negeri 2 Sungai Penuh.
\end{abstract}

Kata Kunci: High Order Thinking Skill (HOTS), Tujuan Pembelajaran, Asesmen, Taksonomi Bloom

Copyright $\odot 2021$ Dinyah Rizki Yanti Zebua, Harmalis

$\triangle$ Corresponding author: Dinyah Rizki Yanti Zebua

Email Address: dinyahryzebua@gmail.com (Jln. KaptenMuradi Sungai Liuk, Sungai Penuh, Indonesia)

Received 28 Januari 2020, Accepted 30 Desember 2020, Published 27 Februari 2021

\section{PENDAHULUAN}

Kurikulum 2013 merupakan sebuah terobosan baru dalam dunia pendidikan Indonesia, pada awalnya hanya diterapkan pada sekolah-sekolah model atau sekolah yang dulu pernah menjadi sekolah rintisan sekolah bertaraf internasional (RSBI). Kurikulum 2013 merupakan penyempurnaan dari kurikulum sebelumnya yang menekankan pada kemampuan yang dimiliki siswa setelah dilaksanakan pembelajaran (Kemendikbud, 2013). Dalam kurikulum 2013 semua mata pelajaran 
Analisis High Order Thinking Skill (HOTs) pada Tujuan dan Asesmen Mata Pelajaran Kimia, Dinyah Rizki Yanti

harus berkontribusi terhadap pembentukan sikap, keterampilan dan pengetahuan dengan menggunakan pendekatan saintifik dalam pembelajaran. Ini lah yang membedakan kurikulum 2013 dengan kurikulum 2006 yang memisahkan antara mata pelajaran yang berkontribusi dalam pembentukan sikap, mata pelajaran keterampilan dan pengetahuan.

Setelah 5 tahun kurikulum 2013 diterapkan, terdapat berbagai masalah yang terjadi dalam penerapannya. Masalah yang tahun ini terjadi dan mendapat perhatian banyak dari publik adalah masalah susahnya soal ujian nasional berbasis komputer. Banyak siswa yang mengeluhkan susahnya soal ujian nasional tersebut. Soal ujian nasional itu menurut Kementerian Pendidikan dan Kebudayaan memuat soal- soal yang menuntut kemampuan tingkat tinggi didalamnya. Masalah susahnya soal ujian nasional ini sempat viral di media sosial Indonesia selama beberapa waktu. Bahkan, Komisi Perlindungan Anak Indonesia sempat mengecam Kementrian Pendidikan dan Kebudayaan yang mengeluarkan soal yang menuntut kemampuan berpikir tingkat tinggi pada ujian nasional tahun 2018 . Kemendikbud sendiri telah berjanji akan mengevaluasi soal ujian nasional tersebut. (Detik News, di Akses 28 April 2018).

Kemampuan berpikir tingkat tinggi atau yang dikenal dengan istilah High Order Thinking Skill (selanjutanya disingkat HOTS), menurut Brookhart (2010; 2014) kemampuan berpikir tingkat tinggi (HOTS) adalah (1) berpikir tingkat tinggi berada pada bagian atas taksonomi kognitif Bloom, (2) tujuan pengajaran di balik taksonomi kognitif yang dapat membekali peserta didik untuk melakukan transfer pengetahuan, (3) mampu berpikir artinya peserta didik mampu menerapkan pengetahuan dan keterampilan yang mereka kembangkan selama belajar pada konteks yang baru. Dalam hal ini yang dimaksud "baru" adalah aplikasi konsep yang belum terpikirkan sebelumnya oleh peserta didik, namun konsep tersebut sudah diajarkan, ini berarti belum tentu sesuatu yang universal baru.

HOTS bukan lah hal baru didunia pendidikan terutama dalam kurikulum 2013. Dalam tujuan kurikulum 2013 dijelaskan bahwa kurikulum 2013 diterapkan dalam rangka mengembangkan peserta didik sehingga memiliki kemampuan yang dapat bersaing dikancah global dan internasional. Untuk itu kurikulum 2013 mensyaratkan bahwa pembelajaran menuntut kemampuan berpikir siswa tingkat tinggi.

Dalam pelaksanaannya, HOTS harus telah tercermin dalam perangkat pembelajaran guru. Guru mengembangkan tujuan pembelajaran dari kompetensi dasar dengan menggunakan kata kerja operasional yang dapa diamati mencakup sikap, pengetahuan dan keterampilan. Pengetahuan dalam kurikulum 2013 mengacu pada taksonomi Bloom revisi oleh Anderson dan Krathwol (2010) dengan enam level tingkatan berpikir yaitu mengingat, memahami, mengaplikasikan, menganalisis, mengevaluasi dan menciptakan. Dimensi pengetahuan juga dibagi menjadi empat bagian yaitu pengetahuan faktual, konseptual, prosedural dan metakognitif. Untuk pembuatan tujuan pembelajaran, guru berpedoman terhadap kata kerja operasional (KKO) yang digunakan untuk pengklasifikasikan tujuan. Dalam perkembangannya, KKO yang sering dijadikan acuan oleh guru dalam 
pengklasifikasian tujuan pembelajaran banyak tumpang tindih dan beririsan sehingga membingungkan guru dalam mengklasifikasikan asesmen yang digunakan. Sehingga evaluasi yang di buat untuk menguji capaian tujuan pembelajaran tidak sesuai dan tidak mencakup pengetahuan mana yang hendak di uji. Kesalahan dalam mengklasifikasi tujuan akan berdampak pada kesalahan dalam menentukan pengetahuan mana dan pada tingkatan berpikir manakah yang harus dikuasai oleh siswa.

Seharusnya guru telah mampu mengklasifikasikan HOTS pada tujuan pembelajaran serta menentukan asesmen yang tepat digunakan untuk mengukur pencapaian tujuan pembelajaran tersebut. Jika guru mampu mngkalsifikasikan, maka HOTS dapat diterapkan langsung dalam pembelajaran dan asesmen sehingga siswa terbiasa dalam menerapkan HOTS dalam kehidupan sehari-hari maupun dalam menjawab soal. Pada kenyataannya penerapan HOTS dalam tujuan dan asesmen pembelajaran belum sepenuhnya dimengerti dengan baik oleh guru.

Dari hasil wawancara diperoleh informasi bahwa pada pelaksanaan Ujian Nasional Berbasis Komputer Tahun ini, siswa mengeluhkan tentang sulitnya soal ujian nasional kimia terutama pada bagian konsep kimia analitik khususnya pada Konsep Asam-Basa. Konsep Asam-Basa merupakan konsep penting dalam mata pelajaran kimia yang banyak berkaitan dengan materi kimia lainnya. Kemudian wawancara yang dilaksanakan dengan salah seorang alumni yang mengikuti ujian nasional berbasis computer pada tahun 2018 juga membenarkan hal tersebut, menurutnya soal ujian nasional berbasis computer sangat berbeda dengan yang mereka pelajari disekolah. Tingkatan soal nya sangat susah terutama konsep asam-basa.

\section{METODE}

Penelitian ini tergolong penelitian kualitatif dengan analisis isi (content analysis). Analisis isi merupakan metode penelitian yang membahas secara mendalam isi suatu informasi tertulis atau tercetak dalam suatu media massa. Penelitian ini dilakukan terhadap informasi yang didokumentasikan dalam rekaman gambar, suara, tulisan atau lain-lain (Suharsimi, 2009). Penelitian ini berusaha memahami pesan simbolik dari sebuah dokumen. Pesan simbolik yang dimaksud dalam penelitian ini adalah HOTS dalam tujuan dan asessment pembelajaran berdasarkan taksonomi bloom revisi. Pengumpulan data dalam penelitian ini melalui studi dokumen terhadap dokumen-dokumen yang didapat dari informan penelitian. Dokumen tersebut meliputi Rencana Pelaksanaan Pembelajaran Konsep Asam Basa dan Soal Ulangan Harian. Analisis data yang digunakan dalam penelitian ini adalah analisis data untuk analisis isi menurut Krippendoff (2004) yang terdiri dari unitizing, sampling, recording, reducing, inferring, dan narrating.

\section{HASIL DAN PEMBAHASAN}

Analisis HOTS pada Tujuan Pembelajaran Mata Pelajaran Kimia berdasarkan Taksonomi Bloom Revisi 


\section{Tujuan Pertama}

Dalam rumusan tujuan pertama pada konsep asam basa ini, dimana tujuan tersebut berbunyi "Siswa dapat menyebutkan contoh-contoh senyawa asam dan basa dalam kehidupan". Kata kerja dari tujuan ini adalah menyebutkan. Kata "menyebutkan" tergolong kepada proses mengingat kembali yang dibutuhkan dari memori jangka panjang. Proses 'mengingat' termasuk kedalam dimensi kognitif C1. Namun jika menelaah kata benda dari tujuan tersebut "contoh-contoh senyawa asam dan basa", maka dimensi kognitif yang dikehendaki guru dalam tujuan ini adalah dimensi kognitif "memahami" (C2). Selanjutnya untuk dimensi pengetahuan,. Jika dilihat dari pengetahuannya, contoh untuk senyawa asam dan basa merupakan hal yang paling dasar yang harus diketahui berkaitan dengan konsep Asam-Basa sehingga digolongkan kepada Pengetahuan Faktual. Dimana pengetahuan faktual merupakan pengetahuan yang berisikan elemen elemen dasar yang harus diketahui siswa dalam mempelajari suatu ilmu.

\section{Tujuan Kedua}

Dalam rumusan tujuan pembelajaran yang kedua yaitu 'Siswa dapat mendekripsikan teoriteori asam dan basa'. Kata kerja operasional didalam rumusan tujuan pembelajaran ini adalah "mendeskripsikan". Kata kerja dalam tujuan ini melibatkan proses identifikasi teori-teori asam basa dan membangun hubungan yang koheren antar teori asam basa tersebut. Karena itu maka dimensi kognitif dari tujuan pembelajaran ini tergolong kepada "menganalisis" (C4). Selanjutnya untuk dimensi pengetahuan, kata benda dari tujuan ini adalah "teori asam dan basa". Kata benda ini mengarahkan kepada pengetahuana pengetahuan tentang teori yang digunakan untuk mendeskripsikan sebuah fenomena. Oleh karena itu maka dari segi pengetahuan, hal tersebut tergolong kepada pengetahuan Konseptual.

\section{Tujuan Ketiga}

Dalam rumusan tujuan pembelajaran yang ketiga yaitu "Siswa dapat mengidentifikasi sifat larutan asam / basa berdasarkan konsep asam / basa dan / atau pH larutan". Kata kerja operasional didalam rumusan tujuan pembelajaran ini adalah "mengidentifikasi". Kata kerja mengidentifikasi dalam tujuan ini melibatkan proses identifikasi sifat larutan berdasarkan konsep. Jika menelaah kedalam kata kerja "mengidentifikasi" maka kata kerja tersebut tergolong kedalam dimensi kognitif "mengingat". Namun, dari kata benda dalam tujuan tersebut "sifat larutan asam / basa berdasarkan konsep asam / basa dan / atau pH larutan" maka dimensi kognitif yang dikehendaki guru dari tujuan pembelajaran ini adalah "membedakan". Membedakan melibatkan proses memilah bagian yang relevan dan penting. Sehingga dalam dimensi kognitif, tujuan ini tergolong pada dimensi "menganalisis" (C4). Selanjutnya penggolongan pengetahuan "sifat larutan asam / basa berdasarkan konsep asam / basa dan / atau pH larutan" tergolong kepada pengetahuan tentang konsep yang digunakan untuk mendeskripsikan sebuah fenomena. Untuk menghitung $\mathrm{pH}$ dari larutan dan 
mengelompokkan sifat nya. Maka ada beberapa prosedur yang perlu diterapkan dan dilakukan oleh peserta didik. Oleh karena itu maka dari segi pengetahuan, hal tersebut tergolong kepada pengetahuan Prosedural .

\section{Tujuan Keempat}

Dalam rumusan tujuan pembelajaran yang ketiga yaitu "Siswa dapat memahami derajat ionisasi dan tetapan kesetimbangan asam/basa". Kata kerja operasional didalam rumusan tujuan pembelajaran ini adalah "memahami'. Kata kerja memahami dalam tujuan ini melibatkan proses pemahaman akan simbol dan terminologi dan juga mengaplikasikan dari teori asam basa ke konsep derajat ionisasi, Karena itu maka dimensi kognitif dari tujuan pembelajaran ini tergolong kepada memahami (C2). Selanjutnya penggolongan pengetahuan "derajat ionisasi dan tetapan kesetimbangan asam/basa" tergolong kepada pengetahuan tentang konsep yang digunakan untuk mendeskripsikan sebuah fenomena. Untuk menghitung $\mathrm{pH}$ dari larutan dan mengelompokkan sifat nya. Maka ada beberapa prosedur yang perlu diterapkan dan dilakukan oleh peserta didik. Oleh karena itu maka dari segi pengetahuan, hal tersebut tergolong kepada pengetahuan Prosedural.

\section{Tujuan Kelima}

Dalam rumusan tujuan pembelajaran yang kelima yaitu "Siswa dapat mengajukan gagasan tentang penggunaan indikator yang tepat untuk menentukan keasaman asam/basa atau titrasi asam/basa”. Kata kerja operasional didalam rumusan tujuan pembelajaran ini adalah mengajukan gagasan. Kata kerja mengajukan gagasan dalam tujuan ini melibatkan proses membedakan indikator untuk mana yang sesuai untuk menentukan keasaman dan kebasaan atau titrasi. Untuk menentukan indikator yang sesuai, maka siswa perlu menganalisa rentang $\mathrm{pH}$ dalam setiap indikator juga sifat serta kegunaan indikator. Karena itu maka dimensi kognitif dari tujuan pembelajaran ini tergolong kepada "menganalisis"(C4). Selanjutnya penggolongan pengetahuan "penggunaan indikator yang tepat untuk menentukan keasaman asam/basa atau titrasi asam/basa" tergolong kepada pengetahuan tentang konsep yang digunakan untuk mendeskripsikan sebuah fenomena. Oleh karena itu maka dari segi pengetahuan, hal tersebut tergolong kepada pengetahuan Konseptual.

\section{Tujuan Keenam}

Dalam rumusan tujuan pembelajaran yang ketiga yaitu "Siswa dapat menghubungkan asam lemah dengan asam kuat serta basa lemah dengan basa kuat untuk mendapatkan derajat ionisasi $(\alpha)$ atau tetapan ionisasi (Ka)". Kata kerja operasional didalam rumusan tujuan pembelajaran ini adalah menghubungkan. Kata kerja menghubungkan dalam tujuan ini meminta siswa untuk dapat menemukan hubungan yang sistematis antara asam kuat, asam lemah, basa kuat dan basa lemah. Karena itu maka dimensi kognitif dari tujuan pembelajaran ini tergolong kepada menganalisis (C4). Selanjutnya penggolongan pengetahuan sifat larutan asam -basa berdasarkan konsep asam-basa dan/atau pH larutan tergolong kepada pengetahuan tentang konsep yang digunakan untuk mendeskripsikan sebuah fenomena. Untuk menghitung $\mathrm{pH}$ dari larutan dan mengelompokkan sifat 
Analisis High Order Thinking Skill (HOTs) pada Tujuan dan Asesmen Mata Pelajaran Kimia, Dinyah Rizki Yanti

nya. Maka ada beberapa prosedur yang perlu diterapkan dan dilakukan oleh peserta didik. Oleh karena itu maka dari segi pengetahuan, hal tersebut tergolong kepada pengetahuan Prosedural.

\section{Tujuan Ketujuh}

Dalam rumusan tujuan pembelajaran yang ketiga yaitu "Siswa dapat memahami prinsip kerja titrasi asam basa". Kata kerja operasional didalam rumusan tujuan pembelajaran ini adalah memahami. Jika dilihat dari kata kerjanya, maka memahami tergolong kepada dimensi kognitif C2. Selanjutnya penggolongan pengetahuan prinsip kerja titrasi asam basa tergolong kepada pengetahuan tentang konsep yang digunakan untuk mendeskripsikan sebuah fenomena. Oleh karena itu maka dari segi pengetahuan, hal tersebut tergolong kepada pengetahuan konseptual. Hasil analisis tujuan pembelajaran selengkapnya dapat dilihat pada Tabel 1.

Tabel 1. Analisis Tujuan Pembelajaran Materi Konsep Asam-Basa Berdasarkan Taksonomi Bloom Revisi

\begin{tabular}{|l|c|c|c|c|c|c|}
\hline \multirow{2}{*}{$\begin{array}{c}\text { DIMENSI } \\
\text { PENGETAHUAN }\end{array}$} & \multicolumn{6}{|c|}{ DIMENSI KOGNITIF } \\
\cline { 2 - 7 } & C1 & C2 & C3 & C4 & C5 & C6 \\
\hline FAKTUAL & & Tujuan 1 & & & & \\
\hline KONSEPTUAL & & Tujuan 7 & & Tujuan 2 dan 5 & & \\
\hline PROSEDURAL & & Tujuan 4 & & Tujuan 3 dan 6 & & \\
\hline METAKOGNITIF & & & & & & \\
\hline
\end{tabular}

Hasil analisis tujuan mata pelajaran kimia pada konsep asam basa menghasilkan bahwa Tujuan mata pelajaran konsep asam-basa ini berada pada dimensi kognitif memahami dan menganalisis. Untuk dimensi pengetahuan berada pada pengetahuan factual, konseptual dan procedural. Beberapa tujuan pembelajaran telah mengarah kepada kemampuan berpikir tingkat tinggi. HOTS berada pada ranah dimensi kognitif C4 - C6.

\section{HOTS (HOTS) pada Asesmen Pembelajaran Mata Pelajaran Kimia Berdasarkan Taksonomi Bloom Revisi}

Data untuk asesmen pada mata pelajaran kimia konsep Asam-Basa, di ambil dari soal-soal ulangan harian siswa SMA N 2 Sungai Penuh. Soal Ulangan Harian terdiri dari 5 Buah Soal. Berikut analisis asessmen penilaian mata pelajaran kimia pada konsep asam basa.

\section{Soal Pertama}

Soal pertama dalam asesmen penilaian kognitif mata pelajaran konsep asam basa adalah "Sebutkan contoh larutan asam dan basa dalam kehidupan sehari-hari". Kata kerja 'menyebutkan' berarti mengambil pengetahuan dari ingatan. Ini mengindikasikan bahwa dimensi yang dikehendaki bagi peserta didik adalah dimensi mengingat $(\mathrm{C} 1)$. Karena disini hanya diminta menyebutkan contoh 
dari larutan asam dan basa. Sementara dimensi pengetahuan yang diminta dalam soal ini adalah pengetahuan Faktual.

\section{Soal Kedua}

Soal kedua dalam asesmen penilaian kognitif ini adalah "Larutan $\mathrm{NH}_{4} \mathrm{OH}$ 0,2 $\mathrm{M}$ mempunyai nilai $\mathrm{pH}=11+\log 2$. Hitunglah nilai $\mathrm{Kb} \mathrm{NH} \mathrm{NH}_{4} \mathrm{OH}$ tersebut". Kata kerja dalam asesmen ini adalah hitunglah/ menghitung. Menghitung dalam nilai $\mathrm{pH}$ dalam soal ini merupakan aplikasi tentang asam atau basa yang ada didalam soal. Selanjutnya akan melalui beberapa langkah dalam menyelesaikan soal ini. Mulai dari menghitung $\mathrm{pOH}$, kemudian $\left[\mathrm{OH}^{-}\right]$selanjutnya dianalisis jenis basa didalam soal untuk diketahui selanjutnya rumus apa yang digunakan. Dimensi kognitif yang dibutuhkan disini adalah dimensi mengaplikasikan (C2) dan pengetahuan yang diperlukan adalah pengetahuan konseptual.

\section{Soal Ketiga}

Soal ketiga dari asesmen penilaian ini adalah "Ke dalam $100 \mathrm{~mL}$ larutan $\mathrm{H}_{2} \mathrm{SO}_{4} 0,1 \mathrm{M}$ ditambahkan $100 \mathrm{~mL}$ larutan $\mathrm{NaOH}$ 0,1 M. hitunglah nilai $\mathrm{pH}$ campuran yang terjadi”. Kata kerja di soal ini adalah hitung atau menghitung. Untuk hal yang diketahui jumlah dan konsentrasinya. Maka dimensi kognitif yang diukur adalah mengaplikasi (C3). Untuk dimensi pengetahuan, karena penyelesaian soal ini memerlukan prosedur yang tepat dan berurut maka dimensi pengetahuan nya adalah pengetahuan prosedural.

\section{Soal Keempat}

Soal keempat dalam asesmen adalah Tuliskan pasangan asam basa konjugasi pada reaksi berikut: $\mathrm{HClO}_{4}+\mathrm{NH}_{2}^{-} \rightarrow \mathrm{ClO}_{4}^{-}+\mathrm{NH}_{3}$. Kata kerja dalam asesmen ini adalah menuliskan, namun untuk menuliskan pasangan asam basa diperlukan pemahaman konsep sehingga dimensi kognitif yang dikehendaki guru adahah memahami (C2). Sementara untuk dimensi pengetahuan, pengetahuan tentang pasangan asam basa konjugasi adalah pengetahuan konseptual.

\section{Soal Kelima}

Soal kelima dalam asesmen adalah Suatu sampel soda kue 0,500 g yang mengandung $\mathrm{Na}_{2} \mathrm{CO}_{3}$ dianalisis dengan menambahkan $50 \mathrm{~mL} 0,100 \mathrm{M} \mathrm{HCl}$ berlebih, dididihkan untuk menghilangkan $\mathrm{CO}_{2}$, kemudian dititrasi kembali dengan 0,100 M NaOH. Jika 5,6 mL NaOH diperlukan untuk titrasi balik, berapa persen $\mathrm{Na}_{2} \mathrm{CO}_{3}$ yang terdapat dalam sampel soda kue? ( $\mathrm{Ar} \mathrm{Na}=23 ; \mathrm{C}=12 ; \mathrm{O}=16$ ). Kata kerja dari soal di atas adalah Menghitung persentase dari senyawa setelah di titrasi. Kata kerja ini menginginkan siswa untuk menganalisis titrasi asam basa setelah penambahan senyawa. Dimensi kognnitif yang dapat diukur dan dikehendaki dari soal ini adalah dimensi kognitif menganalisis (C4). Sementara untuk pengetahuan, dimensi pengetahuan nya adalah pengetahuan prosedural. Hasil analisis selengkapnya dapat dilihat pada Tabel 2 . 
Analisis High Order Thinking Skill (HOTs) pada Tujuan dan Asesmen Mata Pelajaran Kimia, Dinyah Rizki Yanti

Tabel 2. Analisis Asesmen Pembelajaran Materi Konsep Asam Basa Berdasarkan Taksonomi Bloom Revisi

\begin{tabular}{|l|c|c|c|c|c|c|}
\hline \multirow{2}{*}{$\begin{array}{c}\text { DIMENSI } \\
\text { PENGETAHUAN }\end{array}$} & \multicolumn{6}{|c|}{ DIMENSI KOGNITIF } \\
\cline { 2 - 7 } & $\mathbf{C 1}$ & $\mathbf{C 2}$ & $\mathbf{C 3}$ & $\mathbf{C 4}$ & $\mathbf{C 5}$ & $\mathbf{C 6}$ \\
\hline FAKTUAL & Soal 1 & & & & & \\
\hline KONSEPTUAL & & Soal 4 & Soal 2 & & & \\
\hline PROSEDURAL & & & Soal 3 & Soal 5 & & \\
\hline METAKOGNITIF & & & & & & \\
\hline
\end{tabular}

Dari asesmen di atas dapat disimpulkan bahwa di antara kelima asesmen yang di gunakan. Hanya ada satu asesmen yang menguji berpikir tingkat tinggi siswa, yaitu asesmen 5.

\section{Analisis Kesesuaian HOTS pada Tujuan dan Asesmen Mata Pelajaran Kimia Berdasarkan Taksonomi Bloom Revisi}

Dari hasil telaah dan analisis yang mendalam tentang tujuan dan asesmen pembelajaran. Diperoleh bahwa dari 4 buah tujuan yang menghendaki kemampuan berpikir tingkat tinggi siswa, tidak ada satupun asesmen yang sesuai untuk mengukur tingkat berpikir tingkat tinggi siswa. Tujuan dan Asesmen yang dibuat guru tidak relevan. Asesmen yang digunakan tidak sesuai dengan tujuan yang telah dibuat oleh guru dalam pembelajaran.

Ketidaksesuaian antara tujuan dan asesmen yang digunakan untuk mengukur tujuan ini, mungkin dipengaruhi beberapa alasan antara lain (1) Materi pelajaran kimia pada konsep asam basa berisi tentang berbagai konsep yang saling terkait dan memerlukan eksperimen. Guru kesulitan mengajarkan hal tersebut sehingga guru boleh jadi mengubah tujuan pembelajarannya. Asesmen asesmen yang dilakukan setelah pembelajaran berakhir bisa jadi mencerminkan tujuan dan pemahaman baru dan bukan tujuan dan pemahaman yang dirumuskan pada perencanaan pembelajaran, (2) Guru boleh jadi tidak benar-benar memahami tujuan pembelajaran yang dibuat pada perencanaan pembelajaran, dan (3) Sebagian guru merumuskan tujuan-tujuan dalam perspektif jangka panjang. Guru terfokus pada tujuan yang akan dicapai oleh banyak materi yang harus di capai dalam jangka waktu tertentu. Guru mungkin merasa prematur dalam mengases tujuan - tujuan jangka panjang setelah pembelajaran selesai. Asesmen yang prematur akan membuahkan hasil yang secara teknik kurang valid dan dapat melemahkan semangat siswa. Sehingga asesmen tersebut tidak mengukur secara spesifik tujuan yang umum.

\section{KESIMPULAN}

Dari hasil penelitian dapat disimpulkan bahwa HOTS telah terkandung dalam tujuan pembelajaran kimia pada Konsep Asam Basa di SMA Negeri 2 Sungai Penuh, dimana diantara 7 buah tujuan pembelajaran, 4 diantaranya merupakan tujuan pembelajaran yang mengandung HOTS; HOTS telah terkandung dalam Asesmen pembelajaran kimia pada Konsep Asam Basa di SMA Negeri 2 
Sungai Penuh, dimana hanya terdapat satu soal asesmen yang mengandung HOTS; dan tidak terdapat relevansi antara HOTS terkandung dalam tujuan pembelajaran dan asesmen pembelajaran kimia pada Konsep Asam Basa di SMA Negeri 2 Sungai Penuh.

\section{DAFTAR PUSTAKA}

Anderson, L. W., \& Krathwohl, D. R. (2010). Kerangka Landasan untuk Pembelajaran, Pengajaran dan Asesmen (Revisi Taksonomi Pendidikan Bloom). Yogyakarta: Pustaka Pelajar.

Brookhart, S. M. (2010). How to Assess Higher-Order Thinking Skills in Your Classroom. Alexandria: ASCD.

Brookhart, S. M. \& Nitko, A. J. (2014). Educational Assessment of Students. Boston: Pearson Education, Inc.

Kemendikbud, (2013). Permendikbud Nomor 54 Tahun 2013 tentang Standar Kompetensi Lulusan. Jakarta: Kemendikbud

Kemendikbud, (2013). Permendikbud Nomor 64 Tahun 2013 tentang Standar Isi. Jakarta: Kemendikbud

Kemendikbud, (2013). Permendikbud Nomor 65 Tahun 2013 tentang Standar Proses. Jakarta: Kemendikbud

Kemendikbud, (2013). Permendikbud Nomor 66 Tahun 2013 tentang Standar Penilaian. Jakarta: Kemendikbud

Kemendikbud, (2013). Permendikbud Nomor 69 Tahun 2013 tentang KD dan Struktur Kurikulum SMA-MAK. Jakarta: Kemendikbud

Kemendikbud, (2013). Permendikbud Nomor 70 Tahun 2013 tentang Kerangka Dasar Kurikulum SMA-MAK.. Jakarta: Kemendikbud

Kemendikbud, (2016). Permendikbud Nomor 20 Tahun 2016 tentang Standar Kompetensi Lulusan Pendidikan Dasar dan Menengah. Jakarta: Kemendikbud

Kemendikbud, (2016). Permendikbud Nomor 21 Tahun 2016 tentang Standar Kompetensi Lulusan Pendidikan Dasar dan Menengah. Jakarta: Kemendikbud

Kemendikbud, (2016). Permendikbud Nomor 22 Tahun 2016 tentang Standar Proses Pendidikan Dasar dan Menengah. Jakarta: Kemendikbud

Kemendikbud, (2016). Permendikbud Nomor 23 Tahun 2016 tentang Standar Penilaian Pendidikan Dasar dan Menengah. Jakarta: Kemendikbud

Krippendoff. 2004. Content Analysis: An Introduction to Its Methodology 2nd). Thousand Oaks CA : SAGE

Krippendorff, K. (2004). Content Analysis: An Introduction to Its Methodology Thousand Oaks. California: SAGE. 